\title{
VALUES OF TRADITIONAL CULTURE AT STUDENTS OF ARTS SPECIALTY
}

\author{
Liliya Renatovna Zaripova, ${ }^{1}$ \\ Michail Konstantinovich $\mathrm{Yao}^{2}$, \\ Juliana Gennadievna Emanova ${ }^{3}$, \\ Taisiya Pushkar ${ }^{4}$
}

\begin{abstract}
The paper analyzes the value system of students of a creative specialty. Since the end of the 20th century, there have been two opposite trends in social development: the trend of globalization and the trend of national revival based on traditional culture. The value system of globalization includes cosmopolitanism as opposed to patriotism, a mixture of gender and family roles as opposed to the natural separation of sexes; a unified fashion, and virtualization of the public and private spheres. Globalization denies the national characteristics that are embedded in the historical fate of each people and which form the traditional culture. Globalization in the field of culture means the penetration of the same meanings and values with which
\end{abstract}

people endow the phenomena and processes of the surrounding world into all countries with the help of information and communication technologies. Ideals, values, mentality, fashion, methods of communication become the same. The tendency of the revival of the nation is based on the cultivation of traditions, language, mythology, and national mentality. A qualitative study was conducted among second year design students of KFU to identify the dominant values in the minds of students of a creative specialty. In total, there were analyzed 26 texts "In which world I would like to live," in which students described in free form their attitude to the global and traditional world. The tendency was being revealed by the frequency of mentioning preferred

\footnotetext{
${ }^{1}$ Assistant, Department of Design and National Arts, IPIC, Kazan Federal University, lilek1504@mail.ru, ORCID 0000-0001-6871-4438

${ }^{2}$ Candidate of Social Sciences, Associate Professor, Department of Design and National Arts, IPIC, Kazan Federal University, mikhail_yao@mail.ru, ORCID ID: 0000-0001-6868-8161

3 Candidate of Philology Sciences, Senior Lecturer, Department of Design and National Arts, IPIC, emanova-yao@mail.ru, ORCID ID:0000-0001-8 143-203X

4 Doctor of Musical Arts, Distance Learning Lecturer, Manhattan School of Music, taisiyapushkar@gmail.com, ORCID - 0000-0003-4201-0541
} 
GÊNERO E

INTERDISCIPLINARIDADE

ideals, values, and patterns of behavior.

As a result of the analysis, the authors came to the conclusion that the vast majority of students would like to live in a world of traditional values: traditional gender relationships, in a traditional family with a division of social roles, with traditional religious views, but provided that church is separated from state.

Keywords: qualitative research, globalization, traditional culture, values, patterns of behavior.

\section{INTRODUCTION}

Sociologists M. Weber, E. Husserl, A. Schütz, J. Mead drew attention to the cultural subsystem of society, considered it to be dominant in sociogenesis. It is opposed to the Marxist explanation of the change in formations as a result of the growth of productive forces, which were constrained by production relations in each formation. The description of the semantic structure of the social world is based on the knowledge and explanation of the meanings and values that people attach to the phenomena and processes of the world. In turn, the meanings and values
Vol no 02 | nº 01 | ISSN: 2675-7451

https://www.periodicojs.com.br/index.php/gei/index

are formed in the minds of people by cultural codes fixed in aesthetic images, perceptions, experiences, views, evaluations, and judgments .( Karamova, Akhmetshina, 2018). Aesthetic values appear in the subjective world, when an individual knows, and understands the meaning of an object or phenomenon, and gives them some meaning and value for himself .( Karkina, et al. 2018). The first to enter into the subjective world of a person are objects and phenomena of national culture with which a person is connected by the fact of birth .(Yarmakeev,

Akhmadullina, Valiakhmetova, 2018). Their assimilation is included in the task of primary socialization, which takes place in a family, the closest kinship and neighborly environment. The relevance of the study conducted by the authors is to identify students' positions in relation to traditional culture, since they are in the social institute of secondary socialization, when connections with their native area and their immediate environment become weaker.

Tradition (from lat. Traditio transmission, giving) is a universal form of consolidation and transmission of elements of sociocultural experience, and is a mechanism that ensures the continuity of social processes. All 
GËNERO E

INTERDISCIPLINARIDADE

cultural universals, i.e. ideas, norms, values, customs, rituals, ceremonies, holidays, national cuisine, national costume can act as traditions .) Kadyjrova, et al. 2019).Traditions are inherent in all areas of public life: legal, economic, political, scientific, aesthetic, but traditions are of the greatest importance in the religious sphere, since it is the religious worldview that is least susceptible to innovation; it acts as the custodian of stable fundamental values inherent in one or another social community (Abushenko. 2010, p.11341135).

The tradition includes both what is transmitted to new generations as important and necessary for the development of society, and how it is transmitted, in other words, a means of communication in relations within generations and between generations on the basis of cultural heritage accumulated in the past. The behaviour of subjects of social activity, which is regulated with the help of traditions, has already been predetermined, that is, it does not imply the formulation of goals and methods of achieving them: they are justified and legitimized by the very fact of their existence in the past. That is why traditional forms of art (often they act as folk genres and types) exist unchanged
Vol no $02 \mid n^{\circ} 01$ | ISSN: 2675-7451

https://www.periodicojs.com.br/index.php/gei/index

for centuries. All elements of traditions are filled with symbolic content, meanings and values fixed in a particular culture, therefore traditions are sometimes spoken of as conservative, inert, and behavioural models that do not correspond to modern times. These models are not institutionalized, are not supported by laws, but are sufficiently tenacious of life and widespread.

What is the value of tradition, its significance in the modern world, which is constantly being modernized? To answer this question, it is more expedient to apply the method of axiological analysis for a more detailed consideration of the concept of tradition. For the effective functioning of society, traditional value has become the basis and symbol of the common existence of a collective within a certain time interval. The significance of tradition has been emphasized since the preliterate development of individuals. From an evolutionary point of view, tradition remains one of the most fundamental social values that can preserve, streamline and stabilize social development. Maintaining tradition has become a way of survival and procreation. Its foundation is based on the desire to maintain its own viability by transmitting energy, genetic and spiritual 
GÊNERO E

INTERDISCIPLINARIDADE

information to descendants, thereby trying to strengthen the value of the tradition in a historical context. Fear of novelty and the unknown contributes to the formation of traditional value .) Karamova, Rauziev, Akhmetshina, 2019). It is a question of both natural fears based on instincts and on metaphysical ones. A tradition society is characterized by joint decision-making with subsequent collective responsibility. Such a society allows not to be torn between when choosing, facilitates merging with society, and frees from independent determination of goals and objectives in their activities. Tradition forms a strong bond within society and between generations. If we follow it, then the meaning appears and the importance of the person increases. A person feels himself significant in the whole system, which inevitably leads to an increase in his self-esteem. There is a tendency to underestimate the personal element in traditional life. This point of view would be taken as a basis if the individual was considered beyond the scope of tradition. However, active participation in ritual life, following etiquette, following rules and ceremonies expands the individual's personal space, and considering it as a separate from society would not be fair.
Vol no $02 \mid n^{\circ} 01$ | ISSN: 2675-7451 https://www.periodicojs.com.br/index.php/gei/index

A person realizes the generic value, protects the experience of the ancestors, thereby increasing their own importance, despite its extremely low social role in the social system.

In addition, the concept of tradition determines the value of the essence of another individual. The tradition transmitted by ancestors is significant for persons, since they have a feeling of their inseparability from the whole, where other people exist. Admirers and custodians of traditions form strong invisible bonds among themselves. Being a collective phenomenon, tradition fosters awareness of unity with the community. However, not all members of the community are tolerant of other members. Another person is traditionally perceived by an individual as being "necessary for me" both spiritually and in practical terms. Therefore, we can draw the following conclusions. The tradition is a standard developed over the centuries, allowing us to answer the main questions of life. Also, with the help of tradition, a person tries to find the meaning of life and achieve longevity in the life and memory of posterity. Tradition is a means of mutual relations between people within the collective, where the value of one's own being is fully realized through 
GÊNERO E

INTERDISCIPLINARIDADE

interaction with another individual .)

Baeva, 2020). Depending on a particular

social form, whether it is a traditional,

primitive or modernized society,

tradition takes on different meanings.

The primitive form endowed the

tradition with high authority, as it helped

maintain the quality of life and maintain

it for future generations, unite

individuals in space and time, and regulate collective relations. In society, tradition was the basis of spiritual security, minimizing risks and fears when making independent decisions .( Baeva, 2020).

Tradition is considered by a traditional society as a spiritual form. Its manifestation was expressed in an authoritative establishing of the ancestors as founders, in ancient manuscripts, in the importance of repeating examples, in rejection of innovations and the use of settings that were repeatedly tested by life. Tradition serves here as a communication channel that connects the past and present, personality and community. Thanks to tradition, an individual occupied his niche in a society with a certain attitude of other members to it. Ensuring the stability of an individual in social relations, tradition increases the significance and value of the individual
Vol no 02 | nº 01 | ISSN: 2675-7451

https://www.periodicojs.com.br/index.php/gei/index

as a whole, assigns him a place in relations with society providing the necessary rights, obligations and guarantees, helps to correctly solve life problems and gives confidence in the future.

An innovative society sees the value of tradition as a source of movement towards modernization and reforms in society. Modern civilization uses a critical type of thinking to overcome traditional traits. Tradition is also used to rise to a new level. This makes bright use of the principle of continuity, which is widely applied in art, culture, philosophy, and science. Here tradition acts as a driving force ensuring victory over the individual's own conservatism, and allows us to move to new heights. Thus, we can conclude that hereditary information from the past in the form of tradition is of great value for the personal and social development of a person and community; it maintains a temporary connection, and forms a historical basis.

\section{METHODS}

To study the attitude of students of a creative specialty to traditional culture, a qualitative approach was used in the form of an ethnographic method. 
GÊNERO E

INTERDISCIPLINARIDADE

The main principle of this method is the natural collection of data, which consists in an informal approach that does not violate the usual actions of people; in natural conditions (in our case, students wrote texts in a classroom); and in the representation of everyday practices not controlled by a researcher. A detailed description with the interpretation of basic concepts and contextuality sets apart the ethnographic method from others. The description of the studied object "experimenter-personality" should take into account the situation and the conditions in which the study took place (Halitova, Yao, 2014, p.17). The role of the experimenter is important for research using the ethnographic method: the primary task for him is to understand and compare the subject of study, integration into the general flow of information, and close communication with respondents on issues of interest.

The array of empirical data collected by the authors in March, 2020 consisted of 26 texts "In which world I would like to live", where second-year students of the specialty "interior design" described in free form their attitude to the global and traditional world. The tendency was being revealed by the frequency of mentioning the preferred ideals, values, and patterns of
Vol n 02 | ${ }^{\circ} 01$ | ISSN: 2675-7451

https://www.periodicojs.com.br/index.php/gei/index

behaviour. Qualitative research assumes

a free form of presentation of a text; therefore, when analysing, researchers do not correct the stylistic and linguistic errors of the authors.

\section{RESULT AND DISCUSSION}

An analysis of the empirical material collected showed that 6 texts were dominated by global values, but, basically, they were interpreted as an opportunity to travel the world, live and work in any country where they want, live in a world without borders between states. The most common sayings were: "I would like to live in a global world where there are no borders between states"; "I would like to live in a global world where there are no restrictions, there are no prohibitions that prevent people from living the way they want"; "I would choose a global world, and I'm for ensuring that people are not limited to some kind of framework, borders; and they can live as they see fit"; "I am more inclined to global world: to live without borders between states"; "I would like to live in a world where we can travel"; "I would like to live in a global world where humanity will become one family; everyone will be able to live on such a piece of the planet where they feel 
GÉNERO E

INTERDISCIPLINARIDADE

good." We can notice some youthful maximalism and infantilism in the desire to live in a world without borders, without prohibitions, to live as you want, as people see fit. The global coronavirus pandemic at the beginning of 2020 showed how quickly the borders between countries became closed at mortal danger, how difficult it was for governments of all countries to remove their citizens from virus-infected states; so, the idea that all states will live as one family relates to the world of unattainable ideal dreams. Economic confrontations escalating into economic wars, the struggle for territory, the foci of which exist all over the world, have not gone away and will not disappear. Such an idealization of the global world comes, rather, from complete ignorance of the socio-economic and political situation that exists in the modern world.

Students who have chosen the values of global world have a positive attitude towards the values of same-sex marriage instilled by all media: "I have a positive attitude towards same-sex marriage and I think that this is their own choice"; "I have nothing against gay marriage"; "I would like to live in a tolerant society where there are heterosexual and same-sex marriages, in a world where persons can choose their
Vol no 02 | nº 01 | ISSN: 2675-7451

https://www.periodicojs.com.br/index.php/gei/index

own gender, in a world where there are heterosexual and homosexual people, because this is their own choice." There were only 3 such statements; this is a small number among 26 texts, but this is evidence that destructive values that lead to the destruction of the natural foundations of humanity are gradually penetrating into the consciousness of young people.

There are much more texts in which students approve of traditional values: "I would not want to live in a world without borders, in such a global world where recently there has been a tendency to change sex, to same-sex marriages"; "I want the traditional family preserved"; "I am against globalization as a whole"; "I appreciate the traditions of our country; my family and I would not want to lose them"; "A person needs certain boundaries, as permissiveness can lead to chaos"; "I would like for national boundaries and values to remain and people to respect their parents, so that the connection between generations would not broken"; "People should value each other, respect full-fledged families; we need to save our families"; "Children should see an example of a healthy relationship between parents"; "The child must grow up in a full-fledged family with mom and 
GÊNERO E

INTERDISCIPLINARIDADE

dad; when one grows up, he will have someone to take an example from"; "We must not forget about our past, about our ancestors"; "I would not want men to stand and kiss in front of me"; "I would like to live in a world where certain boundaries exist and have value for a person, where national characteristics and traditions are preserved and transmitted, and there are sustainable human values." These statements are supported by data from other sociological studies that testify to the value of a "family" as the highest value among youth: "Universal values for all age categories of youth are family, health, friendship, security, love, justice, and freedom. Moreover, family was named from $93.2 \%$ to $96.3 \%$ in different age categories (Dobrynina, E.P.; 2007, p. 78).

\section{Summary}

In December 2013, the Centre for Scientific Political Thought and Ideology conducted an expert survey to identify the most important values for the country. The changing dynamics and its static state of the interconnected components of society and the state apparatus were evaluated by leading experts. From their point of view, the most important values for Russians were
Vol n 02 | ${ }^{\circ} 01$ | ISSN: 2675-7451

https://www.periodicojs.com.br/index.php/gei/index

as follows: 1. social justice, as $62 \%$ of respondents noted; 2. Sustainability, unity, security and well-being of the country's population were noted by $50 \%$ of respondents; $3.50 \%$ of the survey participants voted for morality; 4. Sovereignty (40\%); 5. State ideology as a collection of values (39\%); 6. Cultural and civilizational identity (37\%) (Sulakshina, 2015, p. 157-158). If we compare the answers of experts, including doctors of science (23\%), candidates of science (54\%) [10, p. 156], we can see that the students' desire to preserve their traditional values coincides with the opinion of the scientific community elite. Of course, in the modern world, where information and communication technologies have turned the globe into a "global village," they have changed the spatial-andtemporal relationship, and penetrated in almost all countries, it is difficult to protect the younger generation from values that destroy the psyche and morality replacing traditional family ties with a "civil marriage", "guest marriage", "Swedish family". And empirical evidence from the study showed that such penetration has already begun.

\section{CONCLUSION}


GÊNERO E

INTERDISCIPLINARIDADE

The main task of the authorities

in our country is to correlate the tasks of sociocultural modernization with historical experience and national cultural heritage. In the modern technological world, it is impossible to draw down the Iron Curtain, close borders, and prohibit travelling to those who gets to know other countries and cultures. But one cannot belittle the role of one's own centuries-old and multinational culture. Along with external foreign tourism, it is necessary to promote domestic tourism in ancient cities and the most beautiful natural corners of Russia. A study of the attitude of students of a creative specialty towards traditional values showed that most young people preferred the culture of their ancestors to trendy tendencies to erase the boundaries between everything and everyone; and constant and unobtrusive propaganda of healthy value orientations is needed. Now it can be done using the Internet, virtualization of the cultural sphere, in a form accessible and sought-after for youth.

\section{ACKNOWLEDGEMENT}

The work is performed according to the Russian Government
Vol n 02 | n 01 | ISSN: 2675-7451

https://www.periodicojs.com.br/index.php/gei/index

Program of Competitive Growth of Kazan Federal University.

\section{References}

Abushenko. V.L. Tradition // The latest sociological dictionary. - Minsk: Book House, 1312 p. (2010).

Baeva, L.V. Preservation of cultural heritage as an embodiment of the value of tradition // Philosophy and Society. Issue No. 1 (65). 2012. - URL: https://www.socionauki.ru/journal/articl es/141559. (2020).

Dobrynina; E.P. Freedom. Inequality. Brotherhood: A Sociological Portrait of Modern Russia / under the general editorship of M.K. Gorshkova. - M.: CEC "Rossiyskaya Gazeta", 448 p. (2007).

Halitova, A.Kh, Yao, L.M. Methodology for the study of sociopolitical processes / A.Kh. Khalitova, L.M. Yao.- M.: Publishing House "ATiSO", 164 p. (2014).

Kadyjrova, L. H., Akhmetshina, E. G., Zaripova, L. R., Peremislov. I. A. Professional Development of Bachelor Designers by Means of Information and Communication Technologies.

International Journal of Innovative Technology and Exploring Engineering 
(IJITEE) ISSN: 2278-3075, vol. 9, №1,

pp. 5119-5122. (2019).

Karamova, K. H. Akhmetshina, E. G.

The model of conditions for training creative self-realization of studentsdesigners// IIOAB JOURNAL. vol. 9, Is.. pp. 88-92, (2018)..

Karamova, K.H., Rauziev, I.Z., Akhmetshina, G.R. / Utilitarian and spirituality of tatar style of living spaces [Utilidad y espiritualidad del estilo t?rtaro de espacios habitables]//Opcion. vol. 35, № 22. pp. 920-933, (2019).. Karkina, S.V., Batyrshina, G.I., Safiullina, L.G., Kovrikova, E.V., Agasaryan , L.S. The sound imitation of some national instruments in piano music // Revista San Gregorio. №27. pp. 6-13. (2018).

Sulakshina, S.S. The problematic agenda of modern Russia / S.S. Sulakshina, D. B. Novikov, A. A. Gaganov, etc. - M.: Science and Politics, 184 p. (2015). Yarmakeev, I.E., Akhmadullina, R.M., Valiakhmetova, N.R, Potential of pedagogical disciplines for forming ethno-cultural competence of students Future teachers//Astra Salvensis. vol. 6, Is.. pp. 275-285. (2018) 